\title{
Tobakksforbruket hos kvinner og menn 1927-2007
}

\begin{abstract}
Sammendrag
Bakgrunn. Etter 100 år med masseutbredelse av sigaretter er røykeepidemien i en begynnende historisk utløpsfase i Norge. Artikkelen viser hvordan antall røykere og tobakkskonsumet fordelte seg på kvinner og menn i perioden 1927-2007.
\end{abstract}

Materiale og metode. Det totale forbruket av tobakk ble beregnet ved å summere det registrerte og uregistrerte salget. Data ble hentet fra Toll-og avgiftsdirektoratet og tobakksindustrien. Kjønnsspesifikk forbruksmengde ble beregnet ut fra opplysninger om andel røykere og selvrapportert daglig konsum fra tidsrekker av representative tverrsnittsundersøkelser.

Resultater. Flere menn enn kvinner rundt 800000 - røykte i begynnelsen av 1960-årene, men den årlige forbruksmengden av sigaretter per voksen mann nådde en topp først i midten av 1970-årene, på 2,8kg. Antall røykere blant menn er halvert, og forbruksmengden ble redusert til 1,5 kg per voksen mann i 2007. Forbrukstoppen blant kvinner kom først rundt 1990 , men stoppet å vokse på 1,8 kg. Antall kvinner som røyker er kun redusert med drøyt 150000 personer siden veksten kulminerte på ca. 600000 personer i begynnelsen av 1970-årene. Menn sto for over $70 \%$ av den akkumulerte mengden sigaretter som ble forbrukt i perioden 1927-2007.

Fortolkning. Menn har vært mest berørt av røykeepidemien. Først etter 1995 konvergerte kvinner og menns røyking.

\author{
Karl Erik Lund \\ kel@sirus.no \\ Marianne Lund \\ Anders Bryhni \\ Statens institutt for rusmiddelforskning (SIRUS) \\ Postboks 565 Sentrum \\ 0105 Oslo
}

Sosiale, demografiske, økonomiske og kulturelle utbredelsesmønstre av sigarettrøyking indikerer at røykeepidemien har nådd en begynnende historisk utløpsfase i Norge. Den idealtypiske røyker har kort utdanning, er middelaldrende, skilt, bor langt nord i landet, er i manuelt arbeid eller helt utenfor arbeidsstyrken (1). Som agenter for trendspredning har de gjenstående røykerne lavt potensial. På bakgrunn av befolkningens høye kunnskapsnivå om helserisiko og et stigende normpress om røykfrihet, er det derfor lite trolig at sigarettrøyking vil komme til å få noen snarlig renessanse. Mest sannsynlig vil ettertiden komme til å anse 100-årsperioden med masseutbredelse av sigaretter som en uheldig parentes i menneskehetens forbrukshistorie. En epidemis utløpsfase innbyr til noen tilbakeskuende betraktninger. I denne artikkelen skal vi dokumentere røykeepidemiens vekst og fall i det 20. århundre $\mathrm{i}$ et kjønnsperspektiv.

\section{Materiale og metode}

Forsyningskildene for tobakk

Det innenlandske salget er blitt registrert av Toll- og avgiftsdirektoratet, og årlige salgsoppgaver finnes fra 1927. Mens omsetningen av rulletobakk er blitt angitt i vekt, har salget av fabrikkfremstilte sigaretter blitt oppgitt i antall. Sistnevnte ble omregnet til vekt ved å sette en sigarett ekvivalent med $1 \mathrm{~g}$ tobakk. Grensehandelen og reiseimport av tobakk utgjør en økende forsyningskilde og er blitt beregnet tidligere (2). For å korrigere for befolkningstilvekst ble den totale forbruksmengden hvert år dividert med antall personer over 15 år bosatt i Norge.

\section{Prevalens av røykere}

\section{og antall sigaretter per dag}

For perioden 1973-2007 er opplysninger om andel røykere blant kvinner og menn og deres konsum av sigaretter hentet fra Statisk sentralbyrås årlige røykevaneundersøkelser. Disse er blitt utført i representative utvalg på $1300-3000$ personer. Svarrespons har vært $63-80 \%$, med fallende tendens over tid (3).

For årene 1956, -57, -58, -60, -64, -66, -70 og -74 ble data om røykeprevalens hentet fra tabellrapporter utgitt av Norsk Gallup Institutt. Antall respondenter var 789-1 054. Responsrate ble ikke oppgitt, men tabuleringer av utvalgene viste på hvert tidspunkt god representativitet på demografiske variabler (4). Supplerende data for perioden 1954-73 ble skaffet fra Nielsen Norways halvårige undersøkelser i utvalg på $6000-10000$ personer (5). Fra 1960 hadde disse tabellrapportene også opplysninger om gjennomsnittlig daglig forbruksmengde av sigaretter.

For perioden før 1954 ble data om andel røykere og forbruksmengde hentet fra en representativ undersøkelse som Kreftregisteret utførte i 1964/65. I denne svarte 7537 kvinner og 6708 menn født i perioden 1893-1927 på spørsmål som gjorde det mulig å rekonstruere røykestatus og forbruksintensitet gjennom livsløpet. Svarrespons var $82 \%$. Rønneberg og medarbeidere har tidligere benyttet flere av de datasett som også er brukt til vårt formål, og det henvises dit for en mer detaljert beskrivelse av data og beregningsmetode (6).

I år med tilfang av data fra flere undersøkelser ble et gjennomsnitt benyttet for å gjøre estimatene mer robuste. For år med manglende opplysninger om daglig sigarettforbruk ble data satt inn ved interpolasjon. For å dempe effekten av tilfeldige svinginger $\mathrm{i}$ materialet ble både andel røykere og daglig forbruk uttrykt med treårig glidende gjennomsnitt.

\section{Kjønnsspesifikt forbruk}

Opplysninger om antall menn og kvinner i alderen 15-74 år bosatt i Norge ble hentet fra Statistisk sentralbyrås statistikkbank for hvert år i perioden 1927-2007. Dette gjorde det mulig å kalkulere antall røykere for hvert kjønn for hvert år i hele 80-årsperioden. Deretter regnet vi ut røykepopulasjonens akkumulerte daglige konsum i hvert kalen-

\section{Hovedbudskap}

- Menn konsumerte rundt $70 \%$ av tobakken som ble brukt i Norge i perioden 1927-2007

- Veksten i kvinners røyking kulminerte på et lavere forbruksnivå enn hos menn

- Kjønnskonvergensen i røyking etter 1990 vil sannsynligvis føre til at kvinner og menn rammes mer likt av sykdommer relatert til røyking 


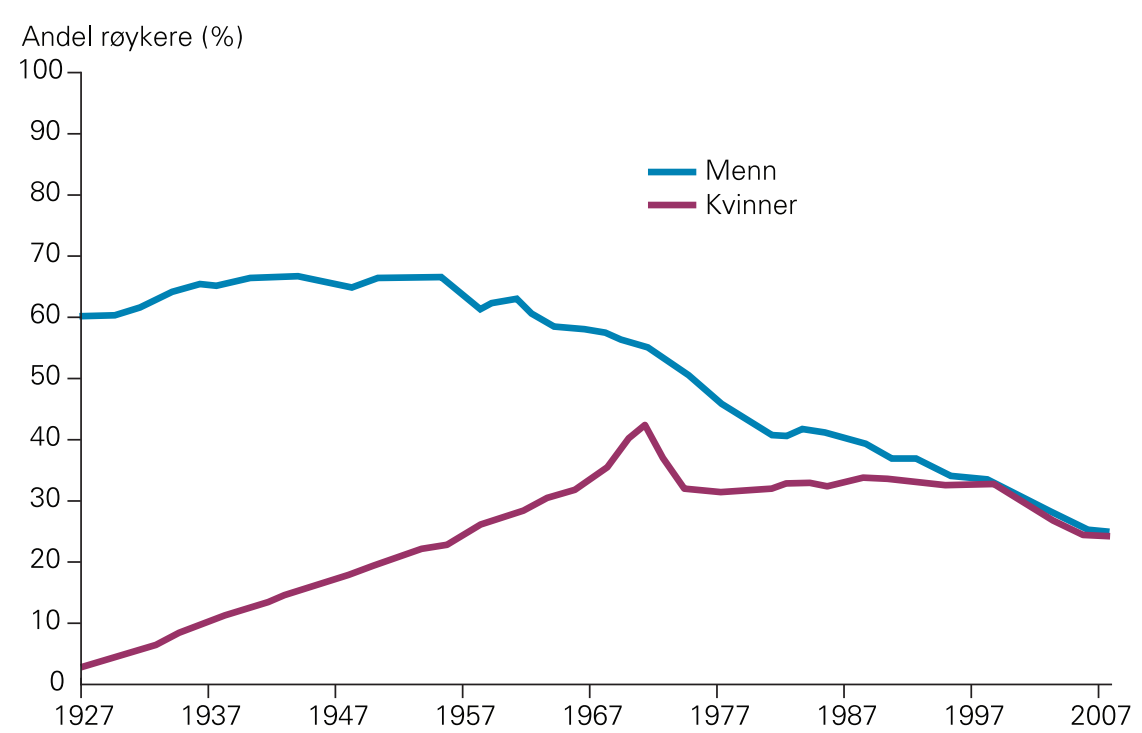

Figur 1 Andel røykere blant kvinner og menn bosatt i Norge i perioden 1927-2007 (treårig glidende gjennomsnitt)

derår ved å multiplisere antall røykere med det selvrapporterte forbruket av sigaretter for henholdsvis kvinner og menn det gjeldende år. Vi kunne dermed regne oss frem til et uttrykk for hvert kjønns prosentvise forbruksandel som både tok hensyn til kjønnsforskjeller i røykeandel og forbruksintensitet. Ved å multiplisere denne andelen med totalkonsumet det gjeldende år kom vi frem til de respektive kjønns forbruksmengde.

\section{Resultater}

Det var stor forskjell i utbredelsen av røyking mellom kvinner og menn ved inngangen til 1930-årene (fig 1). Frem til rundt 1960 røykte rundt $65 \%$ av mennene, sammenliknet med ca. $25 \%$ etter år 2000. Fra et lavt nivå på om-

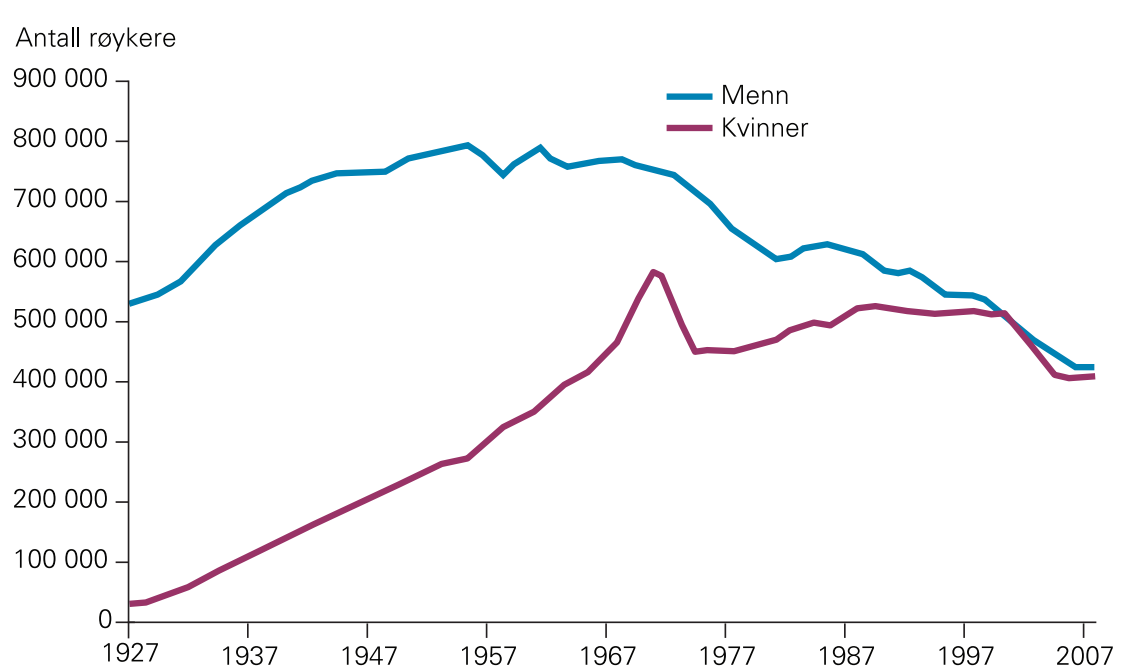

Figur 2 Antall røykere blant kvinner og menn i perioden 1927-2007 gensen i prevalenstallene etter 1995, gjorde denne ulikheten i røykeintensitet at menn fortsatte å konsumere mer tobakk enn kvinner (fig 3). I 1930 sto menn for ca. $95 \%$ av sigarettforbruket, mens de i de siste tiår har konsumert rundt $55 \%$ av kvantumet.

Den årlige forbruksmengden av sigaretter per mann over 15 år nådde $\mathrm{i}$ midten $\mathrm{av}$ 1970-årene en topp på 2,8 kg. Drøyt 30 år senere var konsumet nede i $1,5 \mathrm{~kg}$, omtrent det samme som ved inngangen til 1930-årene. Rundt 1990 så man forbrukstoppen blant kvinner, men denne stoppet å vokse på $1,8 \mathrm{~kg}$. Deretter har konsumet blitt redusert til ca 1,3 kg per voksen kvinne i 2007.

\section{Diskusjon}

Masseutbredelsen av sigarettrøyking i Norge startet med automatiseringen i tobakksindustrien for ca. 100 år siden. Vår undersøkelse viser at menn må ha konsumert over $70 \%$ av alle de sigarettene som er røykt i Norge siden 1927. I et epidemiologisk perspektiv har menn både hatt lengre og en mer intensiv eksponering for sigaretter enn kvinner.

\section{$\emptyset$ kning i sigarettforbruket}

Detaljerte samfunnsvitenskapelige forklaringer på endringen i røykemønstre i Norge er lansert i flere andre arbeider (7, 8). Disse har bl.a. vektlagt at økningen i første halvpart av 1900-tallet skjedde i et samfunnsmessig klima med intensiv reklame der sigarettene signaliserte modernitet, raffinement og eleganse. Pilotene i spredningsforløpet var menn i det urbane borgerskapet - effektive læringsmodeller som bidro til at røyking ble spredt til andre befolkningsgrupper. Røyking blant kvinner var sjeldent, men forekom hyppig i sosiale utgrupper som bohemmiljøet og blant prostituerte. Etter den annen verdenskrig ga myndighetene tobakk status som et nødvendighetsgode og brukte Marshall-hjelpen for å forsyne befolkningen. Røyking hadde en dyp forankring i det sosiale liv, og atferden ble praktisert av bl.a. leger og toppidrettsfolk og ble visualisert gjennom TV-programmer, filmer, avisbilder og reklameannonser. Som rollemodeller må vi anta at legene sendte ganske sterke positive signaler om røyking til allmennheten. I 1952 røykte $74 \%$ av norske mannlige leger og $44 \%$ av de kvinnelige (9). Landets sosialminister deltok i reklame for sigaretter i 1950-årene.

Det tobakksvennlige samfunnsklimaet i 1950- og 60-årene ga meget trange vekstvilkår for den begynnende informasjonen om helsefare ved røyking. Advarslene ble i lang tid kommunisert av moralske entreprenører som mange kanskje oppfattet at var ute på etisk korstog og derfor hadde redusert troverdighet (10). I aviser og lærebøker fantes det liten motvekt til den massive reklamen som glorifiserte røyking (11). Reklamen ble også mer aggressiv fra det tidspunkt da de endelige bevisene for røykingens helserisiko forelå (12). Inntil 1970 holdt legestanden og myndighetene en meget lav profil og var 
fraværende med et tobakkspreventivt engasjement. Den første offentlig finansierte opplysningskampanjen kom først i 1975 fra Statens informasjonstjeneste.

\section{Reduksjonen i sigarettforbruket}

Nedgangen i tobakkskonsumet blant menn startet samtidig med at landet fikk en omfattende tobakkslovgivning. Fra 1975 førte den til et totalt forbud mot all tobakksreklame, innføring av helseadvarsler på tobakkspakkene og en 16-års aldersgrense for kjøp og salg av tobakk. Loven skulle siden bli utvidet med paragrafer som beskyttet mot passiv røyking på arbeidsplasser og transportmidler (1989) og serveringssteder (2004), forbød nye nikotinprodukter (1989), påbød flere (1984) og større (2003) helseadvarsler og høynet aldersgrensen for kjøp og salg av tobakk til 18 år (1995). I tiden etter 1975 økte realprisen på tobakk flere ganger, systematiske avvenningstiltak ble satt i verk, og kampanjevirksomheten ble intensivert.

Myndighetenes innsats har bidratt til å påskynde nedgangen i røyking, men reduksjonen skyldes også mange faktorer utenfor myndighetenes direkte kontroll, slik som røykingens endrede symbolinnhold, brukergruppens deklassering, lansering av nikotinholdige legemidler for røykeslutt og snusens renessanse (7)

\section{Forsinkelser $i$ endringer blant kvinner}

Som vist $i$ figur 1 begynte kvinner å røyke på et senere historisk tidspunkt enn menn. Rønneberg og medarbeidere (6) fant dessuten at sigarettene ble tatt $\mathrm{i}$ bruk på et senere tidspunkt i livsløpet enn hos menn. Denne kjønnsforskjellen må tolkes i lys av de restriktive normer for kvinnerøyking som forelå og som hemmet industrien i å drive kvinnerettet markedsføring. Som gruppe betraktet manglet kvinner typiske innovative kjennetegn som lang utdanning og kosmopolitisk orientering. De var mer religiøse og i større grad administratorer av den private familiære sfære. Kvinner deltok derfor mindre på samfunnsmessige arenaer som kunne virke sekulariserende, normnedbrytende og rekrutterende for røyking $(7,8)$.

Veksten i kvinners røyking hadde rimeligvis sammenheng med liberaliseringen av normene og den påfølgende økningen i kvinnerettet markedsføring (12). Periodene med krig og sosial og økonomisk labilitet hadde virket normoppløsende. Flere kvinner tok også lønnet arbeid og deltok på innrøykte samfunnsarenaer de tidligere hadde stått utenfor.

De røykepreventive tiltakene som etter hvert kom fra myndighetene, inntraff på et tidligere stadium i spredningsforløpet av kvinners røykevaner enn hva tilfellet ble for menn. Dette har trolig bidratt til at veksten kulminerte på et lavere forbruksnivå enn hos menn

Figur 1 viser at nedgangen i kvinners tobakksforbruk startet senere enn hos menn. Dette er forårsaket av en kohorteffekt. I 1970-

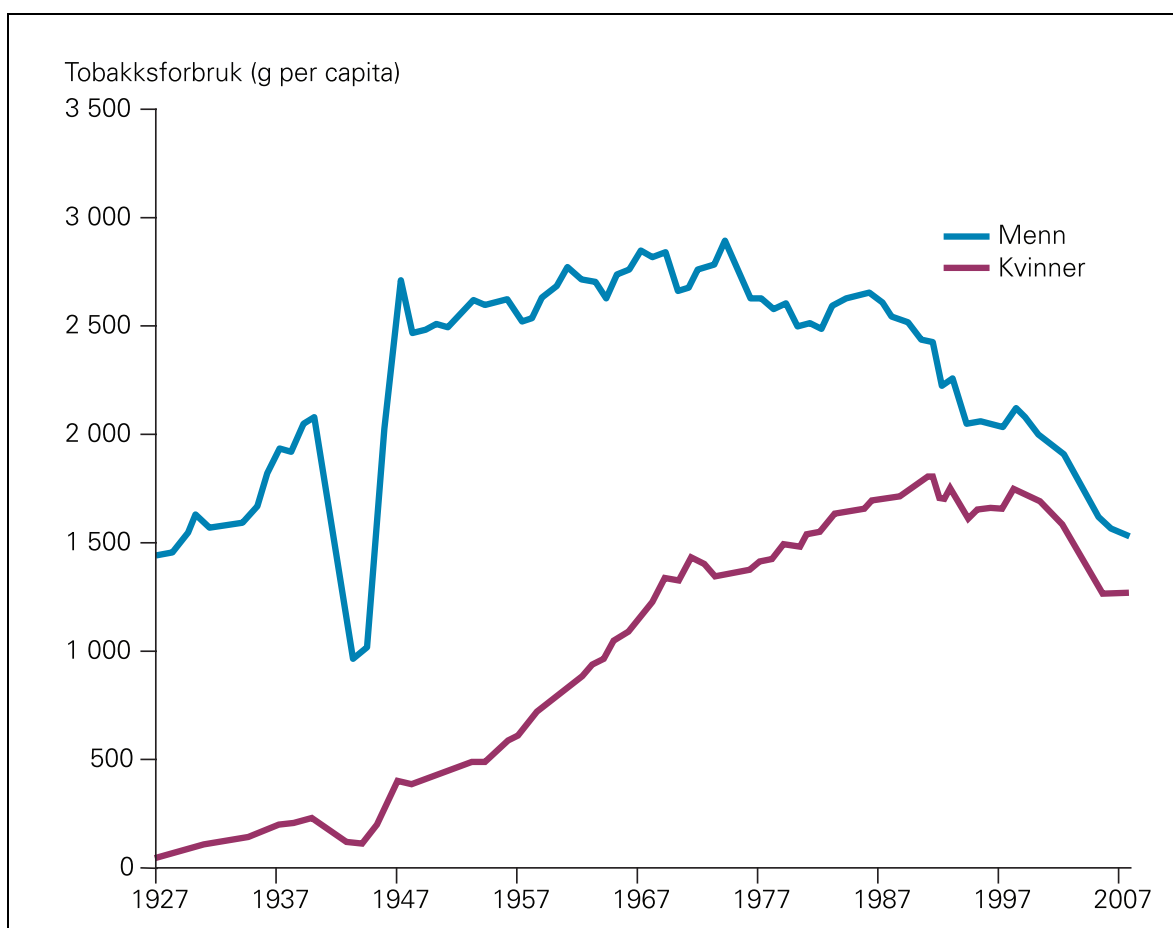

Figur 3 Gram sigaretter konsumert per år for kvinner og menn over 15 år i perioden 1927-2007

årene var det få eldre kvinnelige røykere, noe som skyldtes at det var uvanlig for denne generasjonen å røyke da de var unge i 1920og 30-årene (6). Etter hvert som nye kvinnegenerasjoner - med oppvekst i et mer røykepositivt klima i 1950-årene - erstattet de eldre, har dette bidratt til å utlikne effekten av forbruksreduksjon blant de middelaldrende kvinnene. Frem mot århundreskiftet avtok imidlertid kohorteffekten, og etter århundreskiftet har forbruksreduksjonen vært identisk hos kvinner og menn.

\section{Svakheter ved datagrunnlaget}

Kartlegging av kvinner og menns sigarettkonsum over en periode på 80 år medfører flere måleproblemer både når det gjelder nøyaktigheten av totalforbruket (registrert + uregistrert) og de data om prevalens og intensitet som inngår i modellen for å beregne de kjønnsspesifikke andelene av totalforbruket. For det første kan tobakksindustriens anslag for uregistrert tobakkskonsum etter 1980 en være for høye, fordi de ønsker å presse politikerne til å sette ned tobakksavgiften. Resultater fra representative spørreundersøkelser blant norske røykere om deres forsyningskilder har imidlertid vist ganske god korrespondanse med anslagene fra industrien (2). For det andre finnes det ikke anslag for det uregistrerte tobakkskonsumet under den annen verdenskrig, men ifølge anekdotiske kilder eksisterte det en omfattende hjemmeavling av tobakk som ikke ble registrert. Forbruket i 1940-45 var sannsynligvis vesentlig høyere enn hva våre data viser. For det tredje har vekten på tobakken i de fabrikkframstilte sigarettene blitt noe redusert fra 1980-årene, og omregningen med
1 sigarett lik $1 \mathrm{~g}$ vil resultere $\mathrm{i}$ for høye anslag. For det fjerde har vi ikke data som gjør det mulig å beregne hvor stor del av rulletobakken som er blitt konsumert i pipe. Piperøyking var utbredt blant menn frem til 1970-årene. Vi har heller ikke lagt inn anslag for tobakkskonsumet som stammer fra smugling, men tidligere beregninger har vist at smuglet tobakk utgjør et beskjedent bidrag i totalkonsumet (2).

Fravær av noen årlige observasjoner av prevalens av røykere og røykeintensitet tidlig i perioden gjorde det nødvendig å bruke interpolering og rekonstruksjon. Enkelte punktobservasjoner er derfor mindre pålitelige i tidsrommet 1927-54 enn i senere perioder. Vi antar også at underrapportering av røykestatus i undersøkelsene trolig har økt fordi atferden er blitt mer normavvikende. Til tross for måleproblemene tror vi oversikten i store trekk representerer den faktiske utviklingen i kvinner og menns sigarettforbruk.

\section{Konklusjon}

Masseutbredelsen av sigarettrøyking er om lag 100 år gammel, men tegner nå til å fases ut. I løpet av epidemiens siste 80 år er drøyt $70 \%$ av den akkumulerte mengden sigaretter blitt konsumert av menn. Omfanget av kvinners røyking tiltok senere enn for menn, og konsumet kulminerte på et langt lavere forbruksnivå.

Etablering av denne historiske oversikten over det kjønnsspesifikke tobakkskonsum har vært mulig takket være forsker Alf Rønnebergs arbeider på røykevaner utført ved Kreftregisteret i 1994. Alf Rønneberg døde i 1997. 
Artikkelen er utarbeidet med støtte fra Forskningsrådet som del av prosjektet 190443 «Tobacco behaviour and the social inequality gap».

Oppgitte interessekonflikter: Ingen

\section{Litteratur}

1. Lund KE, Lund M. Røyking og sosial ulikhet i Norge. Tidsskr Nor Lægeforen 2005; 125: 560-3.

2. Lund KE. Omfanget av grensehandel, taxfreeimport og smugling av tobakk til Norge. Tidsskr Nor Lægeforen 2004: 124: 35-8.

3. Nadim M. Reise- og ferieundersøkelsen 2006. En videreføring av SSB's omnibusunders $\varnothing$ kelse. Dokumentasjonsrapport nr. 42/2007. Oslo: Statistisk sentralbyrå, 2007.

4. Norsk Gallup Institutt. Røykevaner. Gallups merkevarebarometer oktober 1974. Oslo: Norsk Gallup Institutt, 1974.

5. Fakta/Norges Markedsdata/Nielsen Norge. Røykevaner. Halvårige rapporter. Oslo: Nielsen Norge, $1954-73$.

6. Rønneberg A, Lund KE, Hafstad A. Lifetime smoking habits among Norwegian men and women born between 1890 and 1974. Int J Epidemiol 1994: 23: 267-76.

7. Lund KE. Samfunnsskapte endringer i tobakksbruk i Norge i det 20. århundre. Doktoravhandling. Oslo: Institutt for sosiologi og samfunnsgeografi, Universitetet i Oslo, 1996.

8. Lund KE. Tobakksbruk - kulturfenomen og risikofaktor. I: Larsen $\varnothing$. Alvik A, Hagestad K et al, red. Samfunnsmedisin. Oslo: Gyldendal Akademisk, 2008: 272-81.

9. Aarø LE, Bjartveit K, Vellar 0 et al. Smoking habits among Norwegian doctors 1974. Scand J Soc Med 1977; 5: 127-35.

10. Lund KE. Det samfunnsmessige grunnlaget for allmennhetens oppfatning om risiko ved røyking i 1950- og 1960-årene. I: Lund KE, red. Grunnlaget for allmennhetens oppfatning om risiko ved sigarettrøyking i 1950- og 1960-årene i Norge. SIRUSskrifter nr. 2/2007. Oslo: Statens institutt for rusmiddelforskning (SIRUS), 2007: 7-48.

11. Kunø N, Graff-Iversen S. Røyking i den populære helselitteraturen i årene 1940-60. Tidsskr Nor Lægeforen 2002; 122: 306-9.

12. Lund KE. Hva kommuniserte norsk tobakksindustri til forbrukerne i reklamen? Tidsskr Nor Lægeforen 2002; 122: 310-6.

Manuskriptet ble mottatt 12.9. 2008 og godkjent 25.6. 2009. Medisinsk redaktør Trine B. Haugen. 